\title{
Divine Revelation as Propositional
}

\author{
R. A. Wellington \\ Ave Maria University
}

\begin{abstract}
In this paper I argue that the propositional model of Divine revelation deserves renewed attention due to both (i) criticisms stemming from misunderstanding and (ii) recent arguments in favor of the propositional model. I begin by clarifying what I mean by the propositional model of Divine revelation and by pointing out misunderstandings of the implications of this model. Subsequently, I offer a few arguments in favor of the propositional model of Divine revelation based on three assumptions that I take to be basic elements of Christianity. Finally, I explain why I think the propositional model is doctrinally significant for the Christian Faith.
\end{abstract}

The propositional model of Divine revelation has been "largely abandoned" by "recent theologians" who find this model of revelation to be too constricting-particularly with respect to Biblical exegesis (Lamont 2004, 5). As a consequence of this abandonment of the propositional model, doctrine runs the risk of being developed and reinterpreted in the absence of a concrete meaning that could only be guaranteed by a formulation and justification of propositions communicated by Divine speech; the sentences of old creeds, if not fixed by definite propositions, cannot ward off revisionist attempts to reinterpret these sentences in a way that is alien to their original context. Of course, this is not to say that all Divine revelation, once it has been received, must merely consist of propositions. Divine revelation, as I will argue, cannot be merely propositional if, by it, we are to have acquaintance with the persons of God. Instead, I agree with Wahlberg $(2014,41)$ that Divine revelation is nothing less than propositional, and as my thesis for this paper, I will defend the idea that the propositional model of Divine revelation deserves renewed attention.

Before proceeding to support my thesis, it would be good for me to stipulate the limits of this paper. First, I cannot offer here a comprehensive defense of the propositional model of revelation; instead, I intend both to explain some common misunderstandings surrounding the propositional model of revelation and to offer a few good arguments in support of the propositional model of revelation. ${ }^{1}$ Second, I will be assuming three key principles that I take to be both basic elements of Christianity since its inception and the current teachings of the Catholic Church: (a)

${ }^{1}$ For fuller defenses of some of these ideas, I refer readers to two principle works that I cite throughout this paper: Lamont (2004) and Wahlberg (2014).

Journal of Analytic Theology, Vol. 7, June 2019

10.12978/jat.2019-7.17-51-51220413

(C) 2019 R. A. Wellington • (C) 2019 Journal of Analytic Theology 
that what is revealed in Divine revelation can be known, ${ }^{2}$ (b) that genuine Divine revelation is true (i.e., "revealing" is a factive verb, ${ }^{3}$ but purported revelations can be either true or false), ${ }^{4}$ and (c) that Divine revelation can be communicated between human persons. ${ }^{5}$ Third, since the debate about the models of revelation seems to me to be chiefly about finding a model of revelation both appropriate to God's special revelation and appropriate to God's revelation offered to the whole Church (i.e., public revelation), I am limiting this discussion of revelation to that of public, special revelation. Fourth, I will not be able to explicate other models of revelation within the scope of this paper.

Given these limits, the paper is organized by the following questions: (I) What is the propositional model of revelation? (II) What are some arguments in its favor? (III) Why is the propositional model significant? After addressing these questions I will offer my concluding thoughts.

\section{What is the propositional model of revelation?}

To begin, the propositional model of revelation is a particular model of revelation which takes the form " $m$ reveals $\alpha$ to $n$ by means of (through, etc.) $k$," 6 and it is a model of revelation that concerns itself primarily with the idea of God speaking: "that God has spoken to humanity, and that the Christian message originates in this speech" (Mavrodes 1988, 88; Lamont 2017, 5). ${ }^{7}$ This is such that $\alpha$ always consists in-but is not merely-propositions: "God's revelation consists in his communicating propositions to humans. He may also reveal himself through other acts; but these other acts are only part of revelation if he also reveals propositions that give the import of these acts" (Lamont 1991, 339). ${ }^{8}$ Further, $k$ is usually a form of speech.

Within the context of speech, "propositions are truth-bearers" that make up the content of anything that can be either true or false (e.g., sentences or thoughts) (Lamont 2004,6). Yet this emphasis on language in the propositional model is not committed to the idea that God literally speaks in human language: "Propositional revelation refers not only to the idea that God reveals by speaking (in the literal sense), but also to other possible modes of revelation, such as the one envisioned by John Locke," namely, God revealing "by directly transmitting true beliefs to some humans" (Wahlberg 2014, 21). These "other possible modes" mean that in the schema

\footnotetext{
2 See Dei Verbum, $\S \S 2,6$, and 15.

3 See Blaauw (2009).

${ }^{4}$ See Lumen Gentium, §16.

${ }^{5}$ See Dei Verbum, $§ 1$.

${ }^{6}$ Of this schema Mavrodes (89) uses $m$ as the revealer, $\alpha$ as the content, $n$ as the recipient, and $k$ as the mean or mode of the revelation. However, Mavrodes notes that $k$ is not "obligatory" for a schema of revelation.

7 See also Dei Verbum, $\S \S 2,4$.

${ }^{8}$ See also ST IIa-IIæ. q.1. a.2. on the propositional character of the faith. For my purposes, ST Ia and ST IIa-IIæ and will refer to the Prima Pars and the Second Part of the Secunda Pars respectively, with "q." as the question, "a." as the article, and "s. c." for "on the contrary," "co." for "I respond that," and "ad." for his numbered reply to the objections.
} 
above, $k$ is not limited to literal speech. Instead, the act of God speaking may be described as God's intended communication to us of the Divine reality, and this primarily takes place in cooperation with human language due to the relationship between our language and our epistemic limitations concerning faith (Mansini 2018): ${ }^{9}$

There is no human cognitive possession of reality that bypasses language (129).... The content of the faith is expressed preeminently in the articles of the Creed, which are propositions. In fact, the content of faith must be expressed in propositions, else God is not speaking to $u s$. For the properly human purchase on reality, and especially where this reality is not and cannot be an object of our immediate experience, is via the proposition.

Of course, since the assent to the proposition depends strictly on our trust in God, we can say, if we want, that faith as trust is more important than faith as assent. But without faith as assent to propositions, faith is as it were empty (223).... It is because this way, the propositional way, is the only way for us that the Church takes the care she does about enunciating dogma, about formulating her traditions, about the exegesis of scripture, indeed, about establishing the letter of the texts of Scripture, about the text of the liturgy. If there were some other way of possessing reality, intelligently grasping the intelligibility of what is possessed, truthfully and so grasping the truth of what is possessed, then the language, the words, the propositions would not matter so much. But there is not. And so they do (261).

In agreement with what Fr. Mansini argues above, I would add that while language is not, itself, the reality that we aim to finally possess, we cannot possess the Divine reality known by revelation independent of language-even in the context of God's deeds. As Mansini says:

But without words, the meaning of the deed is opaque. What would driving the money changers out of the temple mean unless the Lord interpreted it? Christ also has something to give us, too. But we do not know what it is unless he tells us what it is $(2018,260) .^{10}$

The whole of the Gospel - as well as the activity of God in salvation historywould appear strange, or even absurd, in the absence of communication from God via the prophets' language which interprets God's activity. ${ }^{11}$ Without God speaking intelligibly to us to offer an interpretation of His activity, it is not hard to see how Christian theology would be reduced either to a mere superstition-a strange, silent interaction with a Divine Being Who acts without apparent reason and is mistaken

${ }^{9}$ See Dei Verbum, $\S \S 12,13$.

${ }^{10}$ See Lamont $(2004,10)$.

${ }^{11}$ See Lamont $(2004,16)$. 
for fortune rather than for a loving God-or mere Deism. In this way language does not limit God (contra Barth) but frees Him from an impersonal chasm which would otherwise lie between Himself and humanity - a freedom to engage with us on a genuinely personal level. ${ }^{12}$ In addition to this point, Abraham (1982) has questioned whether there can be a coherent account of Divine revelation which excludes Divine speech, writing:

God by definition does not have a body; there is nothing equivalent therefore to our bodily actions by means of which we can begin to guess at what He is doing or what He intends. In His case we are even more dependent on His speaking to us than we are in the case of human agents. Incorporeal agents who do not speak are like invisible men who are dumb. ... This is not to say, however, that we are exclusively dependent on divine speaking. As we have seen, revelation can indeed take place through other actions.... But this in no way detracts from the point that we are to a great degree dependent on divine speaking if we are to have any substantial account both of what God is doing in nature and in history and of His intentions and purposes in acting in creation and in history (15). . . A A theology without the concept of divine speaking has of necessity a God who cannot forgive, command, or make promises. The reason for this is that forgiving, commanding, and promising are performative utterances. To forgive someone their sins is to say sincerely to them, 'I forgive you your sins.' To command y to do $\mathrm{x}$ is to say to $\mathrm{y}$, 'I command you to do $\mathrm{x}$ ', or just to say to $\mathrm{y}$, 'Do $\mathrm{x}$. ' To make promises is to say sincerely, 'I promise ...' To preclude God from speaking not only has serious implications concerning what can be known of God's actions, but also implies fundamental restrictions elsewhere in one's theism (21-22). . . . To claim that God reveals Himself to man but to reject th[at] He reveals Himself by speaking to man is to so whittle away the analogy on which the concept of divine revelation is built that it must be seriously asked whether the concept of divine revelation has enough content to license its continued use. Revelation in the fully personal sense characteristic of personal agents has been abandoned (24).13

Given what Abraham has argued above, it would seem that the coherence of a model of Divine revelation totally lacking Divine speech is dubitable. Yet, this emphasis on Divine speech in the propositional model is not to exclude the fact that God's "plan of revelation is realized by deeds" in addition to His "words" (Dei Verbum, sec. 2). God's actions in history tell us information about God Himself not independent of His words (and His words not independent of His deeds), but the fact that God has revealed something through language or the fact that God has done something in history which

\footnotetext{
${ }^{12}$ See Lamont $(2004,14)$.

${ }^{13}$ See also Abraham $(1981,81)$. Abraham $(1982,9-10)$ describes his attitude toward the propositional model of revelation as "mixed."
} 
manifests God's power, faithfulness, or otherwise is fundamentally propositional. ${ }^{14}$ In light of Biblical reports of God's deeds-that God has acted in history-and His interpretation of those deeds by His words-that God has said such and such-we have knowledge of God that is propositionally based: "the claims that God reveals God, that God broke into history, and that God performed mighty deeds are all propositions, as are the multitude of teachings in the Bible [...] about the nature of God and what God expects from us" (Menssen and Sullivan 2007, 70). ${ }^{15}$

This propositional model of revelation, which suggests such a close connection between language and our reception of Divine truths from God's speaking, need not be confused with Cardinal Dulles's $(1980,52)$ syllogistic characterization of it where he writes, "By the propositional type I mean the theory that revelation is given in the form of ideas that can be adequately expressed in propositional speech-that is to say, in conceptual language that is amenable to syllogistic logic" (emphasis added). Lamont (2004, 9-10) critiques Dulles's equivocation between that which is propositional and that which is "amenable to syllogistic logic," writing:

A propositional assertion is not the same thing as an assertion that uses words literally. Symbolic and metaphorical words and expressions can be used in assertions that are true or false, that can convey information, and that can be the objects of cognitive attitudes.... Nor should we suppose that propositions must be amenable to syllogistic logic. There are many perfectly good inferences from one proposition to another that cannot be described using syllogistic methods.

Although Lamont does not offer an example of an inference from proposition to proposition that cannot be described as syllogistic, I think Grice (1989) offers just such an example with his conversational implicature. ${ }^{16}$ In sum, a conversational implicature takes place when a participant within a conversation implies some bit of information and it can be shown by argument that they imply this information on the basis of Grice's conversational categories and Cooperative Principle (which I will not describe in detail here for the sake of his maxim, "be brief") (27). An example that supports Lamont's point from Grice (32) is as follows:

A is standing by an obviously immobilized car and is approached by B; the following exchange takes place: A: I am out of petrol. B: There is a garage round the corner ... B would be infringing the maxim "Be relevant" unless he thinks, or thinks is possible, that the garage is open, and has petrol to sell; so he implicates that the garage is, or at least may be open. ${ }^{17}$

\footnotetext{
14 See Lamont (1991, 338-44) for a good discussion on revelation as history.

15 See also Swinburne (2007, 3-4; 2009, 129-30).

16 See also Lamont (1991, 337-38).

17 Emphasis on the word "that" added.
} 
Here we can see that a conversational implication of a proposition is shown, and it is not, itself, syllogistic. Thus, we have a propositional account of a linguistic interaction that is not syllogistic.

Lastly, Dulles $(1992,45)$ elsewhere characterizes the propositional model of revelation as "maintain[ing] that supernatural revelation is given in the form of words having a clear propositional content" and that what is "essential to the propositional model" is the "thesis that every declarative sentence in the Bible, unless the contrary can be shown from context, is to taken as expressing a revealed truth." However, this description is problematic: we may say of typical speech acts that they expresses various propositions, but these propositions are not always clearly indicated in the content of the sentences spoken-whether by the conversational implicature I noted above or else by the awareness or limitations of the agents in conversation. Further, both Lamont (1991 and 2004) and Wahlberg (2014) point out that the use of either metaphor or symbolism is not opposed to the propositional model, and Lamont $(2004,17,26)$ indirectly responds to Dulles's argument concerning the inspiration of Sacred Scripture on the propositional model by responding to his characterization of C. H. Dodd's similar argument:

It is quite possible to believe in divine communication, and to believe that the Bible is communicated by God, while recognizing many of the stories in the Bible for what they are, mythical or fictional accounts rather than historical descriptions.... He assumes that a propositional view of revelation is equivalent to the view that the Bible is divinely revealed, and argues that the Scriptures contain quite a lot of falsehood, contradiction and moral error. Divine assertions cannot have these features, so the Scriptures cannot be communicated by God, and since they are not communicated by God revelation is not propositional ... I can only say that Dodd's argument does not establish his conclusion, because he just assumes that it is obvious that the false statements he has in mind are asserted by the biblical text, and this assumption is not obvious; it needs to be based on proof that he does not offer. ${ }^{18}$

Here Lamont points out that the exegesis of Scripture is difficult and that the sentences of Sacred Scripture are not identical with the assertions of Sacred Scripture; Lamont $(2004,8)$ also notes that there is a difference between offering a proposition and asserting a proposition: "propositions are what are asserted, but they are not the same as assertions; assertions are rather a particular use of propositions." ${ }^{19}$ Further, Lamont (14) writes that it would be "unreasonable" for us to suppose that "divine communication consists entirely in God's making assertions" and "one ought not to confuse the claim that God makes assertions with the claim that such assertions are the whole of revelation."

Biblical exegesis, on the propositional model, does not presuppose a literalistic-or an entirely straightforward-view of exegesis, and even of the

${ }^{18}$ See where Wahlberg $(2014,37-39)$ also writes against Dulles's characterization.

${ }^{19}$ See also Wahlberg $(2014,34-35)$. 
propositions asserted within revelation "people can have different degrees of understanding the very same proposition" (Lamont 2014, 219). ${ }^{20}$ In the least, discerning the assertions of Sacred Scripture for the propositional model can be complex-which evinces the problem of oversimplifying the propositional model of revelation like Dulles and Dodd have done. As Wahlberg $(2014,33)$ writes, "the theological literature abounds in confused ideas about divine propositional revelation."

\section{What are arguments in its favor?}

Up to this point I have clarified what I mean by the propositional model of Divine revelation and how it has been misunderstood. In this next section I will proceed by arguing for the propositional model of Divine revelation, and my arguments are built upon the assumptions that I outlined at the beginning of this paper.

\subsection{Assumption (a)}

Given assumption (a) (i.e., that what is revealed in Divine revelation can be known) and that "to reveal" is typically taken to be an act of disclosing something hidden for the purpose of knowledge, we may take revelation to be an epistemic concept. ${ }^{21}$ And insofar as the content of what is revealed can be known, our means of receiving revelation are limited to our means of knowing. Thus, it follows from this that our means of knowing limit what we are capable of receiving in revelation, and the means of our knowing set the means by which God would offer revelation to us-insofar as God desires that we should receive His revelation. The mode of revelation is therefore limited by our means of knowing, and this determines the model of revelation. ${ }^{22}$

Now, our means of natural knowing are limited to roughly three basic categories of knowledge: acquaintance knowledge, procedural knowledge, and propositional knowledge. Although a precise definition of each of these kinds of knowledge would be controversial, I hope to offer a basic discussion of these terms that is sufficient for my case here. To begin, it may be said that one generally has knowledge by acquaintance "when it is truly said of you that you know a person" or thing (e.g., intimate friends know each other or someone may know Vivaldi's music in a way that is not reduced to her knowing that the music was composed by Vivaldi) (Fantl 2017). ${ }^{23}$ But this general sense of acquaintance knowledge may exclude certain kinds of acquaintance knowledge (e.g., the Russellian sense of acquaintance knowledge) wherein one possesses an immediate knowledge a thing without inference from propositions (e.g., sense data). This other kind of acquaintance

\footnotetext{
20 See also Lamont $(1996,396-97)$.

21 See Wolterstorff $(1995,23-24)$ where he argues for the idea that what is revealed is opposed to ignorance.

22 See also ST IIa-IIæ. q.1. a.2. co.

23 See also Stump $(2010,51)$.
} 
knowledge is neither propositional (e.g., that I am immediately aware of sense data $x$ does not capture all of the content of what it means to feel $x$ ) nor procedural (i.e., the content of knowing how to experience something is not, itself, the content of the experience of the thing). Since this Russellian knowledge by acquaintance is neither propositional nor procedural, I will include this kind of knowledge under the broad category of acquaintance knowledge that I am using here. To be clear, I do not mean to restrict acquaintance knowledge entirely to Russell's sense of knowledge by acquaintance whereby one has knowledge by acquaintance "with anything of which we are directly aware, without the intermediary of any process of inference or any knowledge of truths" (i.e., one is immediately aware of one's sense-data, one's self through introspection, one's own memory, and universals) (Russell 2001, 25). Instead, I mean knowledge by acquaintance in a broader sense: one has knowledge by acquaintance of $x$ if and only if she is immediately aware of $x$ (e.g., sense data, introspection, memory) or else if she is mediately aware of $x$ in a way that is not reducible to either propositional knowledge or procedural knowledge (e.g., knowing the personality and character of a person through reputation or contact).

Further, knowledge by acquaintance, in the sense that I am using it, will be a degree concept: in the first way I may be more or less acquainted with my sense data due to disease, drugs, meditation, loss of consciousness, or confusion (e.g., one may be confused about the sense data one is experiencing or one may be confused about the degree to which one is experiencing sense data), and in the second way I may be more or less acquainted with $p$ 's person contingent upon what I know about them or the way in which I have experienced them. On this second way, I am bypassing Russell's negation of the "intermediary of any process of inference or any knowledge of truths" for knowledge by acquaintance of persons. This is because I think that it is possible for one to come to know another person by acquaintance to a degree by a "process of inference or" by some "knowledge of truths" about the person and their effects on the world. For example, one may come to infer from propositional knowledge of a person's effects on the world a knowledge of her person (one may glean her character, preferences, desires, etc.). Yet this collection of knowledge that about the person does not imply that the knowledge arising from knowledge that of the person is also propositional. To know only that $p$ is a good person is not tantamount to knowing $p$ as a good person; the former may arise from knowledge of the fact that $p$ made serious sacrifices in her life for something good whereas the latter may arise either from one's knowledge of the intimate details of those sacrifices or as one being the conscious beneficiary of those sacrifices. In each of these cases, knowledge of $p$ as a good person supervenes on knowledge that $p$ committed the sacrifices that she did (and propositional knowledge concerning the details of those sacrifices), yet the acquaintance knowledge of $p$ as a good person is not reducible to the propositional knowledge that $p$ made sacrifices or that $p$ is a good person. Consider what Stump $(2010,47,53)$ has to say from her distinction between Dominican knowledge (i.e., knowledge that) and Franciscan knowledge (i.e., knowledge not reducible to knowledge that):

there are clear cases of Franciscan knowledge, which is not reducible to knowledge that ... it is not necessary for Franciscan knowledge of 
this sort that there be any direct causal contact between the knower and the person known. Suppose that, unbeknownst to Mary, she had a brother who has since died and that, when Mary is reunited with her mother, her mother gives Mary pictures and stories, Mary may come to know her brother, with Franciscan knowledge, to one degree or another. But she will do so without having "special causal contact" with her brother. At the time Mary comes to know him, he is dead. ${ }^{24}$

Next, one has procedural knowledge "when it is truly said of you that you know how to do something" (Fantl, 2017). This is performative knowledge concerning abilities and skills (e.g., how to move one's limbs, how to ride a bike, how to cook, how to pray). However, I would note that the legitimacy of procedural knowledge as something distinct from propositional knowledge is somewhat controversial from Stanley and Williamson's (2001) work; they have argued that procedural knowledge is reducible to propositional knowledge. ${ }^{25}$ As will be seen below, this controversy does not weaken my arguments since, if procedural knowledge is reducible to propositional knowledge, I do not need to offer some of the arguments that I do in order to defend the propositional model.

Lastly, one has propositional knowledge "when it is truly said of you that you know that some fact is true" (e.g., I know that Queen Elizabeth II is the current queen of the United Kingdom) (Fantl, 2017). Lamont $(2004,9)$ writes that a good test to see whether a kind of knowledge is propositional is to see whether a "that" locution in front of the linguistic expression of the content in question would be sufficient to capture the content of what it is that we intend to express (e.g., I know that Napoleon was defeated at the command of the Duke of Wellington).

Insofar as these are our three categories of natural knowing, we are limited to these basic categories for the kinds of things that we may come to know-except for an important caveat: one might suppose that humans, by the grace of God, are capable of some sort of miraculous knowledge whereby our knowledge escapes the limits of our natural mode of knowing (i.e., knowledge of God's essence in the beatific vision or some other immediate knowledge of God). Now, I am willing to grant this possibility-if not affirm it. However, further discussion of this caveat is excluded from this paper due to the third limitation that I outlined at its beginning (i.e., that we are dealing exclusively with public revelation). This is because any kind of miraculous knowledge is not available for public knowledge in the way that public revelation is, and we are dealing with models for public revelation. Thus, insofar as knowledge of Divine revelation is knowledge of the supernatural-but not miraculous knowledge-miraculous knowledge cannot offer an adequate rebuttal against my case here. ${ }^{26}$

24 For a fuller defense of the idea that acquaintance knowledge is not reducible to propositional knowledge, see Stump (2010, chapters 3 and 4).

25 See also Stanley (2011a and 2011b).

26 Russellian knowledge by acquaintance, wherein one is immediately aware of God (e.g., sensus divinitatis), is ruled out from this discussion as a matter of scope and relevance (not by rejection); we are dealing with public revelation and so public knowledge of the supernatural-instead of miraculous knowledge or private knowledge of the supernatural. Insofar as our problem is restricted to the 
On these three categories of knowledge, we may settle for the propositional model of revelation if propositional knowledge is the only adequate form of knowing by which we may have knowledge of what is revealed in Divine revelation. Now, if we suppose that knowledge of Divine revelation is intended to give us knowledge of God, then the relevant question for our evaluation of the three kinds of knowledge will be the following: how can we come to know God by the public content of Divine revelation? Our evaluation of the ability of these three kinds of knowledge to answer this question begins as follows: first, it seems obvious that Divine revelation contains various instructions for procedural knowledge, and this fact may give us the impression that procedural knowledge-if it is not reducible to propositional knowledge-is something that could not be adequately communicated on the propositional model of revelation. Thus, it would seem that the propositional model is inadequate for the communication of procedural knowledge from God.

In order to address this problem, I would first note that not all procedural knowledge will be relevant for our discussion. This is because some procedural knowledge might have been known by natural reason instead of by special revelation (e.g., independent of the historicity of the Old Testament's account of the Israelites receiving procedural knowledge from God, some procedural knowledge that God is reported to have given the Israelites-such as how to avoid the spread of some diseases or how to defeat certain enemies-could have been discovered by a clever person without special revelation). Yet procedural knowledge knowable by natural reason, instead of exclusively by special revelation, does not help us with our project of finding a model for public, special revelation-which is meant to tell us things that we could not know on our own. ${ }^{27}$ Thus, I will focus on what I term special procedural knowledge. Special procedural knowledge, for my use, is procedural knowledge that could only be known by special revelation (e.g., after the disciples asked, "Lord, teach us to pray, as John taught his disciples" Jesus taught them how to pray the Lord's Prayer-which I take to be an item of procedural knowledge that could only be known by special revelation) (RSVCE: Lk. 11:1). ${ }^{28}$

Now, this special procedural knowledge is not tantamount to knowledge of God-it is only knowledge that may help us to enter into an intimate relationship with God. Further, this special procedural knowledge presupposes propositional knowledge both about the revelation and from the revelation itself (e.g., in the case of Jesus teaching His disciples how to pray, the disciples presuppose that Jesus, Himself, knows how to pray, that God is the sort of God Who would hear their prayers, and they believe that the content of the Lord's prayer is a pious way to address God the Father). Lastly, any special procedural knowledge procured from Divine revelation that affects one's epistemic relation to God supervenes on the propositional knowledge that this revelation is credible (i.e., that it has a sufficient probability of having God as its initial origin and guarantor) and that God's instructions are reliable

problem of developing a model of public, special revelation, we must rely on a knowledge base that is, itself, also public and shareable. Russell $(2001,32)$ concludes that knowledge by acquaintance cannot get "us to pass beyond the limits of our private experience" (that is where his knowledge by description comes in).

${ }^{27}$ See ST Ia, q.1, a.1, co. See also Swinburne $(2007,80 ; 2008,66)$.

${ }^{28}$ For a good discussion on the Lord's Prayer see "Chapter 5: The Lord's Prayer" from Ratzinger (2007). 
(i.e., both that God's intentions are good in communicating the special procedural knowledge and that God is in a privileged epistemic position sufficient to offer us efficacious instructions or advice on the things that He instructs or advises us on). On these reasons we can see that propositional knowledge, as it relates to a model of special Divine revelation, is epistemically prior to special procedural knowledge. Thus, we can see that in whatever way special procedural knowledge disposes us to knowledge of God, we must rely on propositional knowledge from special revelation for special procedural knowledge; our foundation for special procedural knowledge is, therefore, propositional revelation.

Second, it would seem that through Divine revelation we come to an acquaintance knowledge of God whereby we know Him intimately; thus, it would seem that acquaintance knowledge is a good candidate for a complete account of knowledge of Divine revelation. However, I think that such an account would be incomplete: although acquaintance knowledge is distinct from propositional knowledge, it seems to me that knowledge by acquaintance of persons (in whatever way one is acquainted with persons through a public means instead of by a private means) is mediated by propositional knowledge. One does not sufficiently possess acquaintance knowledge of another person through public means except by possessing propositional knowledge of that person (e.g., where they are from, what their values and preferences are, what habits they have, what their occupation is, who their friends are, what they possess, what they have said or done, how they have said or done something). Taken in this sense acquaintance knowledge, although distinct from propositional knowledge, supervenes on propositional knowledge.

In this way, knowledge of God by Divine revelation may-and ought-to become an acquaintance knowledge of God, but the type of knowledge of Divine revelation that yields acquaintance knowledge is propositional knowledge. Along a similar line of reasoning, Lamont $(2004,13)$ writes, "We do not have a self-disclosure of God in revelation instead of a communication of knowledge. Rather it is in part through a communication of knowledge that God's self-disclosure takes place." With similar reasoning Abraham $(1981,80)$ writes:

If God were to communicate certain propositions to an individual then that in itself would normally entail that God has revealed something of himself. Thus if God were to say "I am faithful to my covenant with my people Israel," this would reveal something about God himself. It is misguided, therefore, to insist that any revelation made by asserting propositions somehow contradicts the claim that the content of revelation is God himself. Indeed such verbal revelation is crucial to our understanding of God.

This emphasis on propositions as a vehicle for God's self-disclosure is the substance of what I meant in the introduction of this paper by the idea that Divine revelation is not less than propositional: that this propositional revelation is meant to fundamentally unite the human person to God in a disclosure of God that offers a higher kind of knowledge than that of propositional knowledge-an acquaintance knowledge from propositional knowledge. Thus we might say that the propositional 
model of revelation is the foundation of Divine revelation but that "revelation is a broader concept than divine speaking" (Lamont, 2004, 5).

In this way, Divine revelation offers propositions, but it offers more than just propositions, particularly in cases of manifestational revelation whereby we are even more apt to acquaintance knowledge (Wahlberg 2014):

Revelation is an epistemic concept: it has to do with knowledge, and knowledge is, or involves, a propositional attitude (an attitude toward a proposition). Propositions, therefore, necessarily figure in both propositional and manifestational revelation. God, or any agent, cannot make knowledge of some reality available to a subject except by making knowledge of some proposition available. So even though manifestational revelation does not essentially involve propositions known by the revealer, it still essentially involves propositions as the entities revealed. ... In manifestational revelation, therefore, the entities revealed can (and often do) include more than just propositions, while in nonmanifestational revelation they include only propositions. If God appears to a person in a mystical experience, or as the incarnate Son of God in Palestine two thousand years ago (which would be examples of manifestational revelation), then God reveals both some proposition about himself (propositions, as we remember, figure necessarily in any kind of revelation), but also something that is not a proposition, namely God himself (30-31)... . [R] [evelation indeed is more than a transmission of information. The crucial point is that it cannot be less (41).

In a similar way, St. Thomas Aquinas (ST IIa-IIæ. q.1. a.2. ad.2.) writes that "the act of the believer does not terminate in a proposition, but in a thing." 29 This is such that God's revelation always consists in-but offers more than-propositional content. This propositional content is, itself, not the object of the revelation but the threshold that we cross to enter into acquaintance. ${ }^{30}$ The object of the revelation-that to which the propositions refer-is God. Thus, by the propositions of revelation we develop acquaintance with God, and this knowledge by acquaintance is itself distinct from propositional knowledge. It "is non-propositional and... is not reducible to knowledge that" even though it arises from or accompanies (in the case of manifestational revelation) propositional knowledge (Stump 2010, 51). ${ }^{31}$ As Lamont $(1996,407)$ writes, "Divine revelation is not primarily a set of first aid instructions for dealing with sin, or a set of directions that tell us how to find our way to God." Instead, it is a means of bringing "us into a personal relationship with Christ. It does contain some first aid instructions and directions, but these are all based on this

\footnotetext{
${ }^{29}$ Mansini $(2018,223-24)$ argues against interpreting Aquinas to exclude the propositional character of faith on this point. See also Lamont $(2004,8)$.

${ }^{30}$ For a good discussion on revelation as a threshold concept, see Abraham (2006).

${ }^{31}$ Here I am hoping to accommodate some of Stump's $(2010 ; 2013,53)$ worries that knowledge of God is sometimes reduced to mere propositional knowledge, or mere knowledge that.
} 
personal relationship, and presuppose it." Wahlberg $(2014,14-15)$ seems to agree here as well:

I do not think that revelation is only, or principally, about grasping propositions. I think that revelation is mainly about getting to know a person, Jesus Christ. Furthermore, I believe that coming to know Christ through revelation requires a graced transformation, which is effected by participation in the sacramental life of the church. Revelation, therefore, involves much more than divinely asserted propositions.

\subsection{Assumption (b)}

On assumption (b) (i.e., that genuine Divine revelation is true) we reason (i) there are purported Divine revelations that turn out to be true (e.g., we suppose that various Old Testament prophecies referred to the future life, death, and resurrection of Christ, and these turned out to be true instead of false), and (ii) there are those that turn out to be false (e.g., various prophecies in non-Christian religions or in extremist sects). ${ }^{32}$ Further, (iii) purported Divine revelations between religions conflict with each other-as Johnson writes (1994, 199-200):

The propositional force of religious beliefs cannot be underestimated. The reason religious beliefs conflict is not because the differences are only surface level ones. Rather, when two religious believers begin to converse they soon find out that the differences are fundamental and irreconcilable. Real differences exist between religions because they make both explicit and implicit ontological claims-they "claim objective states of affairs for their beliefs" about God, the aims or meaning of life, the human condition and so on.

Finally, we may say that (iv) the content of purported Divine revelation may turn out to be either true or false with reference either to creation or to the Divine reality beyond this world (e.g., to say that God is truly triune is to say something that both refers to God and is substantially true of God in a meaningful way-such that its contrary, "God is not triune," is false).

From (i)-(iv) we can see that purported Divine revelations are capable of being either true or false, either with reference to creation or with reference to the Divine reality, but genuine Divine revelation will turn out to be true. Yet, this admittance to the truth of Divine revelation is just to presuppose that Divine revelation is something that could be true, and this is just to say that Divine revelation-in whatever way it is true-is propositional since propositions are the

\footnotetext{
32 See Dei Verbum, $§ 15$.
} 
exclusive means by which things are said to be true, ${ }^{33}$ or judgeable in the words of Geach $(2005,361)$ :

In St. John's account of Christ's prayer to his Father after the Last Supper, Our Lord said, "Thy word is truth." As at the beginning of the Gospel, "word" stands for the Greek word "logos." To approach the subject of truth I shall begin by talking about logos.... The "logos" we get in the Creeds is the sort of "logos" we use to express what we believe or know. Not all "logos" is apt for this. Consider the difference between "Priam's wooden palace" and "Priam had a wooden palace." We find "logos" in both, but only the second is apt to express belief. To borrow an expression from the German logician Frege, only the second string of words has a content that is "beurteilbar," judgeable. Judgeable content need not be actually judged: we get the same content when, like Alice, we only say "if ..." or when we ask a question that can be answered "yes" or "no." But it is precisely judgeable content that puts us in the position to assert, truly or falsely.

All too often we hear it said that Christian belief is not belief that so-and-so, but belief in or trust in a Person. In one of his writings Chesterton countered this by remarking that in order to trust my mother I must believe that I have a mother and believe that the person with whom I am conversing is indeed my mother. And we read in the Gospel. "These things are written in order that you may believe that Jesus is the Christ, the Son of God."

In line with what Geach argues above, we cannot hope to have Divine faith and trust in Christ without first knowing that Jesus is the Son of God and knowing that God is good and trustworthy. In this way, sufficient acquaintance with the whole person of Jesus of Nazareth, Who is both Divine and human, supervenes on the propositional knowledge that Jesus is the Son of God, the Christ, the Messiah, God Incarnate, the

\footnotetext{
33 Two points are in order on this claim. First, there may be ambiguities of "true" that mean "genuine" (e.g., "you are a true soldier") or that mean "accurate" or "apt" (e.g., "his aim was true"). But it seems to me that "true" in a non-ambiguous sense-and in a sense excluding reference to the ontological truth of God's Being - must exclusively designate elements of language, and it must, within these elements of language, designate statements-or propositions-if it is to escape vacuity.

Second, it might be argued that a religion may be true in a non-propositional sense, by way of "correspond[ing] or not correspond[ing] to what a theist calls God's being and will" so "that its objectives are interiorized and exercised by groups and individuals in such a way as to conform them in some measure in the various dimensions of their existence to the ultimate reality and goodness that lies at the heart of things" (Lindbeck 1984, 52). However, a religion as lived and interiorized to correspond to reality strikes me more as a form of justice rather than one of truth, and that this interiorized religion corresponds to any reality at all is a matter of propositional truth-particularly revealed propositional truth if it corresponds to the Divine reality. Other notions of "true" in religion (e.g., categorical) would be better considered as dispositions-or, at least, useful tools-for discerning truth rather than being forms of truth themselves. The claim here is that truth, even religious truth, is said of the proposition which is considered by the mind disposed categorically and existentially to receive or formulate it.
} 
Second Person of the Trinity, the Word, the Son of Mary, etc. There cannot be full acquaintance with the person of Jesus as He is without knowledge of that which He is, and there cannot be a recognition of Divine revelation as true without presupposing that revelation is something that could be true (i.e., that it consists in propositions). ${ }^{34}$

\subsection{Assumption (c)}

On assumption (c) (i.e., that Divine revelation can be communicated between human persons), two arguments may be mounted-the first of which I will only touch upon briefly. These arguments aim to show the following: first, that everything expressed in language is propositional and, second, that any revelatory content communicated through language must be propositional. These two arguments are logically distinct such that if a theologian or philosopher rejects the view that everything which can be expressed in language is propositional, the second argument-which rests on the meaning of "revelation"-may still succeed.

Lamont $(1991,337)$ takes up the first line of argument, writing that "if something can be expressed in language, it is a proposition." He goes on to argue that if the content of revelation can be expressed in language-if Holy Scripture really does contain revelation-then the content of revelation is propositional. However, while I will not defend his argument here for the sake of brevity, I would encourage those interested in this idea to look at both his understanding of the relation between language and propositions ${ }^{35}$ and the argument that he offers from this understanding. ${ }^{36}$ Thus, in case Lamont's thesis is too controversial or unconvincing and one holds that not everything that can be expressed in language is propositional-as is the view of Mavrodes $(1988,119-22)$ - I will proceed with the second argument from assumption (c).

On assumption (c) (i.e., that Divine revelation can be communicated between human persons) it follows that Divine revelation is the sort of thing that is expressed by language and ideas: God's "plan of revelation is realized by deeds and words" (Dei Verbum, sec. 2) (emphasis added). In this way, Divine revelation must be able to be expressed in language, and language is intimately linked with propositions such that any substantial use of language must also involve a substantial use of propositions: "propositions form the content of much language" (Lamont, 2004, 7). Now, communicative acts are not restricted to the use of propositions as Lamont $(2004,9)$ and Mavrodes (1988, 119-22) point out (e.g., expressions like “ouch!"), but God's use of language, according to Mavrodes, may be non-propositional (e.g., by asking questions for purposes other than finding answers or by issuing commands without intending for the commanded act to be completed). ${ }^{37}$ However, I will contend that if there is Divine communication that is not propositional, any use of language to convey revelatory content must be propositional. Consider Mavrodes's $(1988,122)$ view:

\footnotetext{
34 See Lamont (1991, 337).

35 See Lamont $(2004,6-10)$.

36 See Lamont (1991, 337).

37 In contrast, Lamont $(2004,8)$ argues that questions do have propositional content.
} 
It seems to me, therefore, that there is not much chance that functions of such speech acts as questioning and commanding could be replaced by the asserting of propositions. ... If we take seriously, then, the possibility of a divine speaking to human beings, we should be careful not to think of it purely in terms of the asserting of propositions, or of the conveying of information.... But the verb 'to reveal' does not seem to be really idiomatic when the content of what is said is a question. Nor, it seems to me, does it go really naturally with commands and requests. I suspect that this is a terminological point without much deeper significance. If I am right about that, then we can resolve it in one way or another. We can stretch the term 'revelation' a little beyond its common usage, and make it cover questions, commands, and perhaps even some other sorts of speech acts. Or we can leave the notion of a communication-type revelation pretty well tied to information and propositions, and then say that the divine speaking also involves other sorts of communication that are not revelationsuch things as questions and commands. Here I adopt the first alternative. But I have no objection to anyone who prefers the second. ${ }^{38}$

Of these two views of revelation listed by Mavrodes, I think that the second view of revelation is the only appropriate use of "revelation," and I think that it is not a "terminological point without much deeper significance" for two reasons.

First, communicated revelatory content is a distinct subclass of communicated content-the former denoting content which would remove ignorance of something significant for the recipient of the revelation, the latter denoting content which needn't remove ignorance of something significant for the recipient of the communication. ${ }^{39}$ This difference is between removing ignorance of that which we could not know on our own for the sake of salvation (i.e., special revelation) and the mere communication of truths. Second, questions (or commands) do not fit our typical meaning of "revelation" except by revealing either that something has been asked (or that something has been commanded) or else by the implications or presuppositions of the thing asked (or commanded)-these implications or presuppositions being propositions. For example, "Do you know what time it is?" is a question that may reveal (a) that the person asking is curious about the time or (b) by implication that the person of whom the question is being asked ought to consider what time it is and its relation to the situation of the conversants (e.g., that she should to go to a meeting, that he should close up shop, or some other proposition). Independent of these propositions, I see nothing else contained within this question that could count as revelatory-or as something being opposed to ignorance in

\footnotetext{
${ }^{38}$ Even of communicative content expressed by commands or questions that is not revelatory, I do not know what exactly is supposed to have been said unless its content is propositional, but for my purposes here, I will not pursue this matter further.

${ }^{39}$ See Blaauw's $(2009,7-8)$ argument in support of the idea that revelation involves a high-stakes situation for the recipient of the revelation.
} 
Wolterstorff's presentation of revelation that I referred to earlier in this paper. Except by presupposing or implying propositions, questions do not reveal; declarative sentences functioning as answers to questions are more apt to be called revelatory under the appropriate conditions of relieving ignorance of something both hidden from and significant for the recipient of the revelation.

Further, commands are revelatory only insofar as either they reveal the fact that God is commanding some action or else they reveal by presupposition or by implication propositions indirectly. They are revelatory insofar as they satisfy the appropriate conditions of relieving ignorance of something both hidden from and significant for the recipient of the revelation. For example, if God commands for $y$ (where $y$ is some agent) to $z$ (where $z$ some action), what could be revealed is that God desires a state of affairs wherein $z$ obtains due to $y$ 's causing $z$ (e.g., commanding the Law through Moses-see Ex. 20), or that God has special knowledge pertaining to either $y$ or $z$ (e.g., Jesus commanded a Samaritan woman to call her husband only to reveal that He knew about her having five lovers—see Jn. 4:7-30), or that God wishes to show something significant about $y$ or about $z$ by commanding $y$ to $z$ (e.g., commanding Abraham to kill his son Isaac-see Gn. 22:1-18). What is revealed here is propositional; a command, if its presuppositions and implications were excluded, would not be revelatory in any sense consistent with our typical use of "revelation" except to say that this command took place is revelatory. Communication from God is not revelatory unless God's communication is disclosing something (i.e., information or God Himself) that is hidden from and significant for the receiver of God's communication.

From these arguments we can see that God's revelation to humanity, as it is shared between humans, is linguistic, but the content of revelatory language is propositional. Thus, revelation, as it is communicated between human persons, is propositional.

\section{Why is the propositional model significant?}

Up to this point I have clarified, defended, and argued for the propositional model of Divine revelation. In this brief section I aim to defend the importance of holding a propositional model of Divine revelation.

To begin, Mansini $(2018,129-30)$ articulates the dangers of holding an "extrapropositional" account:

The experiential or connatrual knowledge of revealed mysteries is sometimes thought of as an extra-propositional, extra-linguistic possession of the mysteries of salvation, and this makes it easy to explain the emergence of dogmatic formulas that are not deduced or otherwise easily lead out from the words of Scriptures.... [This] is an important mistake, moreover, because it is tantamount to removing the limits on what we can know and say about the mysteries, the limits of Scripture itself. From hearers of the word we soon move to become 
architects of our own spirituality. The doctrines of the Church become symbols in the modern sense, imaginatively pleasing images on which we hang our hopes and desires-except that they are not pleasant, like the doctrine of original sin, and then we discard such a "symbol" as no longer serviceable for Christian thought and action. In other words, an appeal to a non-linguistically mediated experience of God easily passes into a barely concealed report of what we ourselves think is good for us to think and good for us to do, and forfeits any pretension really to communicate what has been heard from God.

In addition to this danger articulated by Mansini whereby we both become the "architects" of our own spirituality and form Christianity into a paradigm of our own desires (instead of having Christianity form us and our desires), I would add that the (total) rejection of the propositional view of revelation cannot but nurture revisionist attitudes within the Church. If the creeds and declarations of the Church are not taken to have a fixed meaning - which can only be guaranteed by propositions-in a way that renders the contrary of such declarations theologically untenable for a faithful theologian, then the creeds and declarations of the Church have said nothing substantial.

Further, if, through a non-propositional model of revelation, doctrine is permitted to have its meaning re-assigned in a way that does not preserve the intentions of its originators (and the Originator Who inspired them), then the unity of Christian belief across time becomes illusory. This is not to say that meaning fixed by a proposition is one that cannot be developed, but such a fixing restricts the development of doctrine from being twisted by revisionists to mean its contrary. As Wahlberg $(2014,36)$ writes:

a view of revelation that posits divine assertions is not necessarily "static" and incompatible with critical scrutiny. If propositional revelation is "static," it is so only in the sense that it entails that God's revelation has, as one of its aspects, a determinate cognitive content. This means that our interpretations can get what God says more or less right. It might not always be easy to distinguish more or less correct interpretations from each other, but some are more correct than others. This is just another way of saying that God actually says something.

In this way, propositional revelation restricts development insofar as that development would be revisionist-hence the revisionist may find it to be static. But the propositional model is static in its meaning only insofar as it really means something, and a thing can only mean something if it does not mean other things. To begin to say something meaningful is, at the same time, to deny many other things by implied contradiction. And it is in supposing, as Christians, that God has said something meaningful to us that we conclude that the void between God and man has been bridged in a way that is personal, and therefore linguistic, and therefore propositional. 


\section{Conclusion}

Throughout this paper I have clarified, defended, and argued for the propositional model of Divine revelation. I began by outlining some key assumptions that I take to be basic elements of Christianity since its inception and are taught by the Catholic Church. Subsequently, I argued that if we accept these key assumptions, then we should hold a propositional model of Divine revelation. To do otherwise, as I pointed out, runs the risk of forming Christianity into a paradigm of our own spiritual desires, denying any revealed truth in Christianity, and rejecting that God has reached out to us in a personal way. To conclude, I think that the propositional model of Divine revelation is not merely a model of Divine revelation among other models from which the faithful Christian may pick to realize her faith. Rather, I think that the faithful Christian is already predisposed to favor the propositional model of Divine revelation due to the propositional character of her faith. For to even be a Christian, in some sense, is to affirm that what Christ has said is true, that one's faith should be consistent with the witness of the Apostles and in continuity with historical Christianity, and that non-Christian religions are not true in whatever way they conflict with Christianity. None of these things can be adequately expressed nonpropositionally, and yet to be a Christian is to hold each of these propositions to be true. 


\section{Bibliography}

Abraham, William James. 2006. Crossing the Threshold of Divine Revelation. Wm. B. Eerdmans Pub Co.

. 1982. Divine Revelation and the Limits of Historical Criticism. Oxford University Press.

1981. The Divine Inspiration of Holy Scripture. Oxford University Press.

Aquinas, Thomas. 1947. Summa Theologica, translated by Fathers of the English Dominican Province. Benziger Bros. edition. Accessed June 5, 2018. https://dhspriory.org/thomas/summa/

Blaauw, Martijn. 2009. "The Nature of Divine Revelation." The Heythrop Journal 50 (1): 2-12.

Dulles, Avery Robert. 1992. Models of Revelation. Doubleday Books.

. 1980. "The symbolic structure of Revelation." Theological Studies 41 (1): 5173.

Fantl, Jeremy. 2017. "Knowledge How." In The Stanford Encyclopedia of Philosophy, edited by Edward N. Zalta. Accessed June 5, 2018. https://plato.stanford.edu/archives/fall2017/entries/knowledge-how/

Geach, P. T. 2005. "Truth.” New Blackfriars 86 (1004): 361-364. doi:10.1111/j.00284289.2005.00091.x.

Grice, H. Paul. 1989. Studies in the Way of Words. Harvard University Press.

Johnson, Wayne George. 1994. "The Possibility of Revelation in non-Christian Religions in the Thought of Paul Knitter: an Evangelical Analysis and Critique." PhD diss., Trinity Evangelical Divinity School.

Lindbeck, George A. 1984. The Nature of Doctrine. The Westminister Press.

Lamont, John R. T. (2004). Divine Faith. Routledge. . 1996. "Stump and Swinburne on Revelation." Religious Studies 32 (3): 395411.

. 1991. "The Nature of Revelation." New Blackfriars 72 (851): 335-45.

Mansini, Guy. 2018. Fundamental Theology. The Catholic University of America Press. 
Mavrodes, George. 1988. Revelation in Religious Belief. Temple University Press.

Menssen, Sandra and Thomas D. Sullivan. 2007. The Agnostic Inquirer: Revelation from a Philosophical Standpoint. Wm. B. Eerdmans Publishing.

Paul VI. 1965. Dei Verbum [Dogmatic Constitution on Divine Revelation]. Vatican Website. Accessed copy made on June 28, 2017. http://www.vatican.va/archive/hist_councils/ii_vatican_council/documents /vat-ii_const_19651118_dei-verbum_en.html.

- 1964. Lumen Gentium [Dogmatic Constitution on the Church]. Vatican Website. Accessed copy made on May 5, 2018. http://www.vatican.va/archive/hist_councils/ii_vatican_council/documents /vat-ii_const_19641121_lumen-gentium_en.html.

Ratzinger, Joseph. 2007. Jesus of Nazareth: From the Baptism in the Jordan to Transfiguration. Translated by Adrian J. Walker. Doubleday.

Russell, Bertrand. 2001. The Problems of Philosophy. Oxford University Press.

Stanley, Jason. 2011. Know How. Oxford University Press.

. 2011. “Knowing (how)." Nous 45 (2): 207-38. doi:10.1111/j.14680068.2010.00758.x.

Stanley, Jason, and Timothy Williamson. 2001. "Knowing How." The Journal of Philosophy 98 (8): 411-44.

Stump, Eleonore. 2013. "Athens and Jerusalem: The relationship of philosophy and theology." Journal of Analytic Theology 1 (1): 45-59. 2010. Wandering in Darkness: Narrative and the Problem of Suffering. Oxford University Press.

Swinburne, Richard. 2009. "Revelation." In Oxford Readings in Philosophical Theology: Volume 2: Providence, Scripture, and Resurrection, edited by Michael Rea. Oxford University Press.

2007. Revelation: From Metaphor to Analogy, 2nd edition. Oxford University Press.

2008. Was Jesus God? Oxford University Press.

Wahlberg, Mats. 2014. Revelation as Testimony: a Philosophical-Theological Study. Wm. B. Eerdmans Publishing. 
Wolterstorff, Nicholas. 1995. Divine Discourse: Philosophical Reflections on the Claim that God Speaks. Cambridge University Press. 